\title{
Crude protein and supplemental dietary tryptophan effects on growth and tissue neurotransmitter levels in the broiler chicken*
}

\author{
BY R. W. ROSEBROUGH \\ Growth Biology Laboratory, Livestock and Poultry Sciences Institute, United States Department of \\ Agriculture-Agricultural Research Service, Beltsville Agricultural Research Center, Beltsville, \\ $M D 20705, U S A$
}

(Received 13 March 1995 - Revised 26 July 1995 - Accepted 24 November 1995)

Indian River male broiler chickens growing from 7 to $28 \mathrm{~d}$ of age were fed on diets containing 120, 210
and $300 \mathrm{~g}$ crude protein/kg diet and $0,1-67$ or $16.7 \mathrm{~g}$ added tryptophan (TRP)/kg diet. The hypothesis
tested was that crude protein levels and TRP would affect both growth and neurotransmitter metabolism.
Heart, brain and pancreatic neurotransmitter (noradrenaline (NA), dopamine (DA), serotonin (5-HT)
and 5-hydroxy-indole-3-acetic acid (5-HIAA)) concentrations were determined by HPLC separation and
electrochemical detection. Malate dehydrogenase (2-oxoglutarate decarboxylating) (NADP + )
(MDH(NADP + ); EC 1.1 .1 .40 ), isocitrate dehydrogenase (NADP + ) (ICD(NADP +);
EC 1.1.1.42) and aspartate aminotransferase (AAT; EC 2.6.1.1) activities were also measured.
Supplemental TRP decreased growth and feed intake. Increasing dietary crude protein decreased
MDH(NADP + ), but increased (ICD(NADP + ) and AAT activities. Additional dietary TRP decreased
MDH(NADP + ) activity, but had no effect on other enzyme activities. Cardiac NA concentrations were
directly related to dietary crude protein levels while pancreatic levels were inversely related. An increase
in dietary crude protein decreased both brain NA and DA. Supplemental dietary TRP increased both 5-
HIAA and 5-HT. Changes in feed intake caused by different levels of both dietary crude protein and
TRP are accompanied by altered levels of neurotransmitters. The present study indicates that much
larger amounts of TRP are required to make simultaneous changes in feed intake and neurotransmitters.

Protein: Tryptophan: Neurotransmitters: Chicken

The central nervous system (CNS) of rats responds to changes in dietary regimens and regulates eating behaviour (Young \& Landsberg, 1977a). The addition of both carbohydrates and fats to diets without changing the total energy level activates the sympathetic nervous system (Young \& Landsberg, 1977b; Schwartz et al. 1983). Later studies suggested that substitution of either sucrose or glucose for dietary protein would also stimulate neural activity (Kaufman $e t$ al. 1984; Vander Tuig \& Romsos, 1984; Young et al. 1985). A more recent study indicated that dietary energy components might also change the rates of dopamine (DA) and noradrenaline (NA) turnover in rats (Kaufman et al. 1989). The addition of casein raised urinary DA excretion while carbohydrate or fat supplementation decreased urinary DA.

A relationship also exists between consumption of protein and carbohydrate and the synthesis of serotonin (5-hydroxytryptamine; 5-HT) by the brain (Fernstrom, 1983). Serotonin is synthesized from the essential amino acid L-tryptophan (TRP) and may regulate feed intake in rats (Nielsen et al. 1992). The initial step involves the hydroxylation

* Mention of a trade name, proprietary product or vendor does not constitute a guarantee or warranty of the product by USDA or imply its approval to the exclusion of other suitable products or vendors. 
of TRP to form 5-hydroxytryptophan (5-HTP), which is catalysed by TRP hydroxylase (EC 1.14.16.4) (Fernstrom, 1979). The major 5-HT metabolite in the brain is 5-hydroxyindole-3-acetic acid (5-HIAA) and its relationship to 5-HT is indicative of 5-HT turnover (Colmenares et al. 1975).

There is a shortage of information concerning the effect of dietary components on the metabolism of the CNS in birds. Smith \& Waldroup (1988) found no effect of TRP on growth variables. It should be noted that this experiment was designed primarily to determine a dietary requirement of TRP for growth and may not have been optimal for studying CNS responses. In a later study, Denbow et al. (1993) reported that supplemental TRP increased brain 5-HT, 5-HIAA and NA concentrations in young turkeys without affecting body-weight gain, feed efficiency or feed intake. In the latter study the levels of supplemental TRP were only slightly greater than those used in the former study $(1-3 \mathrm{~g} / \mathrm{kg}$ diet). It could be deduced from these two studies that small additions of TRP to diets will probably have little or no effect on feed intake even though additions change brain biogenic amines.

In contrast to the above feeding experiments that changed brain biogenic amines without altering feed intake, biogenic amines injected into chicken brains have been shown to change feeding responses, depending on the site of injection. For example, injection of NA into the preoptic and paraventricular areas of the brain increased feed intake, while injection of NA into other areas of the brain decreased feed intake (Denbow \& Sheppard, 1993). An intracerebroventricular injection of 5-HT decreased feed intake in birds that had been fasted for $24 \mathrm{~h}$. Moreover, applying this protocol to lines of birds selected for rapid bodyweight gain revealed that selection for weight gain also sensitized birds to the inhibitory effect of 5-HT on feed intake (Lacy et al. 1987). At least in rats, it can be shown that 5-HT antagonizes NA-stimulated feeding by reducing meal size and frequency (Leibowitz \& Shor-Posner, 1986). It has not been shown that birds selected for rapid weight gain have an enhanced noradrenergic-mediated appetite control mechanism that would account for results in the Lacy et al. (1987) study. A previous study by this group (Denbow, 1983) did reveal that feeding responses of egg-type chickens following the injection of biogenic amines were different from those of broiler-type chickens.

We have reported several times that broiler chickens eat less of a diet containing $120 \mathrm{~g}$ crude protein $/ \mathrm{kg}$ diet than of one containing $180 \mathrm{~g}$ crude protein $/ \mathrm{kg}$ (Rosebrough \& Steele, 1985; Rosebrough et al. 1992; Rosebrough \& McMurtry, 1993). Birds fed on diets containing low levels of crude protein also grow poorly and are proportionately fatter than are birds fed on diets containing higher levels of crude protein. In this respect, feeding a diet containing a low level of crude protein produces bird that is metabolically similar to the egg-laying bird. Might it also be possible that tissue biogenic amine concentrations would also be similar to those in the egg-laying bird? The present experiment was designed to test the effects of crude protein and TRP on growth and neurotransmitter metabolism. The activities of certain enzymes involved in the control of intermediary metabolism were also monitored to assess the effects of TRP on pathways distinct from the CNS.

\section{MATERIALS AND METHODS}

\section{Animals}

Male, Indian River broiler chicks growing from 7 to $28 \mathrm{~d}$ of age were assigned to one of nine dietary treatments. These treatments consisted of three levels of crude protein (120, 210 and $300 \mathrm{~g} / \mathrm{kg})$ and three levels of added TRP $(0,1.67$ or $16.7 \mathrm{~g} / \mathrm{kg}$ diet $)$ arrayed in a $3 \times 3$ factorial arrangement. Some characteristics of the diets are described in Tables 1 and 2. The chickens were housed in battery-brooders in an environmentally controlled room 
Table 1. Composition of the basal diets $(\mathrm{g} / \mathrm{kg}$ diet $)$

\begin{tabular}{lccc}
\hline \hline & \multicolumn{3}{c}{ Dietary crude protein $(\mathrm{N} \times 6 \cdot 25)(\mathrm{g} / \mathrm{kg}$ protein) } \\
\cline { 2 - 4 } & 120 & 210 & 300 \\
\hline Ingredient & & & \\
Soyabean meal & 100 & 325 & 550 \\
Maize meal & 790 & 552 & 315 \\
Maize oil & 30 & 40 & 50 \\
Sand & 20 & 20 & 20 \\
Dicalcium phosphate & 40 & 40 & 40 \\
Limestone & 10 & 10 & 10 \\
L-Methionine* & - & $2 \cdot 5$ & 5 \\
Selenium premix $\dagger$ & 1 & 1 & 1 \\
Mineral premix $\ddagger$ & 1 & 1 & 1 \\
Vitamin premix§ & 5 & 5 & 5 \\
Iodized salt & 3 & 3 & 3 \\
Calculated composition & & & \\
Metabolizable energy $(\mathrm{MJ} / \mathrm{kg})$ & $13 \cdot 5$ & $12 \cdot 8$ & $12 \cdot 1$ \\
Lysine $(\mathrm{g} / \mathrm{kg})$ & $6 \cdot 0$ & $11 \cdot 4$ & $16 \cdot 8$ \\
Sulphur amino acids $(\mathrm{g} / \mathrm{kg})$ & $10 \cdot 3$ & $11 \cdot 3$ & $12 \cdot 3$ \\
\hline \hline
\end{tabular}

* L-Methionine (18915), US Biochemicals, PO Box 22400, Cleveland, Ohio 44122, USA.

$\dagger$ Provided $0.2 \mathrm{mg} \mathrm{Se} / \mathrm{kg}$ diet.

$\$$ Provided (mg/ $\mathrm{kg}$ diet): manganese 100, iron 100, copper 10 , cobalt 1 , iodine 1 , zinc 100 and calcium 89 .

$\S$ Provided (mg/kg diet): retinol 3.6, cholecalciferol 0.075, biotin 1, $\alpha$-tocopherylacetate 10 , riboflavin 10 , pantothenic acid 20 , choline $2 \mathrm{~g}$, niacin 100 , thiamine 10 , pyridoxine 10 , menadione sodium bisulphite $1 \cdot 5$, cyanocobalamin $0 \cdot 1$, pteroylmonoglutamic acid 2 and ethoxyquin 150.

Table 2. Calculated composition of the diets

\begin{tabular}{ccccc}
\hline \hline $\begin{array}{c}\text { CP } \\
\text { (g/kg diet })\end{array}$ & $\begin{array}{c}\text { Added TRP } \\
\text { (g/kg diet) }\end{array}$ & $\begin{array}{c}\text { LNAA* } \\
(\mathrm{g} / \mathrm{kg} \mathrm{diet})\end{array}$ & TRP:LNAA & $\begin{array}{c}\text { Total TRP } \\
\text { (g/kg diet) }\end{array}$ \\
\hline 120 & 0 & 32.6 & 0.038 & 1.24 \\
120 & 1.7 & 32.8 & 0.089 & 2.91 \\
120 & 16.7 & 32.8 & 0.549 & 17.91 \\
210 & 0 & 53.8 & 0.045 & 2.43 \\
210 & 1.7 & 53.8 & 0.076 & 4.09 \\
210 & 16.7 & 53.8 & 0.355 & $19 \cdot 09$ \\
300 & 0 & 73.7 & 0.048 & 3.57 \\
300 & 1.7 & 73.7 & 0.070 & 5.24 \\
300 & 16.7 & 73.7 & 0.274 & 20.24 \\
\hline
\end{tabular}

CP, crude protein; TRP, tryptophan; LNAA, large neutral amino acids.

* Tyrosine, phenylalanine, leucine, isoleucine and valine.

maintained at $23^{\circ}$ with a $12 \mathrm{~h}$ light-dark cycle (06.00-18.00 hours light). Treatments were randomly assigned to pens in each battery. The experiment was repeated twice for a total of eight pens of six chickens each for each dietary treatment. Both feed and water were apportioned on an ad libitum basis. At $28 \mathrm{~d}$ of age, one bird from each pen was randomly selected and killed. In the first repetition, livers were removed into liquid $\mathrm{N}_{2}$ and stored at $-70^{\circ}$. In the second repetition, brains, hearts, livers and pancreata were removed into liquid $\mathrm{N}_{2}$ and stored at $-70^{\circ}$. 


\section{Neurotransmitters}

Organs from the second experimental repetition were homogenized in $0 \cdot 1 \mathrm{M}-\mathrm{HClO}_{4}$ (PCA) $(1: 10, \mathrm{w} / \mathrm{v})$ and centrifuged at $12000 \mathrm{~g}$ for $15 \mathrm{~min}$. For NA and DA analyses, a $2 \mathrm{ml}$ portion of the resultant supernatant fraction was added to $2 \mathrm{ml} 1.5 \mathrm{M}$-Tris-50 mM-EDTA (pH 8.6) containing $100 \mathrm{mg}$ acid-washed alumina (Anton \& Sayre, 1962). Dihydroxybenzylamine (DHBA; $5 \mathrm{ng}$ ) was added to each sample as an internal standard. Then, each sample was mixed for 2 min to trap catechols on the alumina. The alumina was then washed five times with $10 \mathrm{~mm}$-Tris and catechols were then eluted with $1 \mathrm{ml} 0.1 \mathrm{M}$-PCA.

Analyses of catecholamines were performed by modifications of the method of Eriksson \& Persson (1982). The chromatography system consisted of a pump (PM-48: Bioanalytical Systems, West Lafayette, IN, USA), a reverse-phase column $(100 \times 3.2 \mathrm{~mm}$, ODS Phase II: Bioanalytical Systems) and a glassy-carbon amperometric detector (LC-4B: Bioanalytical Systems). The mobile phase was a monochloroacetate buffer (150 mM) containing $1 \mathrm{~mm}$ EDTA and $1 \mathrm{~mm}$-sodium octyl sulphate at $\mathrm{pH} \mathrm{3.0.} \mathrm{The} \mathrm{organic} \mathrm{modifier} \mathrm{was} \mathrm{acetonitrile}$ $(50 \mathrm{ml} / \mathrm{l})$. The electrochemical detectors were set at $+0.65 \mathrm{~V} v . \mathrm{Ag} / \mathrm{AgCl}$ reference electrode with ranges of 5 and $50 \mathrm{nA}$ for NA, DHBA and DA.

Analyses of indolamines were achieved by injecting portions of the PCA extract into the HPLC without any intermediary trapping step. The mobile phase was a monochloroacetate buffer (150 mM) containing $1 \mathrm{~mm}$-EDTA and $1 \mathrm{~mm}$-sodium octyl sulphate at $\mathrm{pH} 3 \cdot 0$. The organic modifiers were acetonitrile $(40 \mathrm{ml} / 1)$ and tetrahydrofuran $(10 \mathrm{ml} / 1)$ respectively. The detectors were set at $+0.80 \mathrm{~V}$ and $+0.65 \mathrm{~V} \mathrm{v}$. a Ag/ $\mathrm{AgCl}$ reference electrode and 5 and $10 \mathrm{nA}$ for 5-HT and 5-HIAA.

\section{Enzyme assays}

Livers from both experimental repetitions were homogenized $(1: 10, \mathrm{w} / \mathrm{v})$ in $50 \mathrm{mM}$-HEPES (pH 7.5)-3.3 mM- $\beta$-mercaptoethanol and centrifuged at $50000 \mathrm{~g}$ for $60 \mathrm{~min}$ (Rosebrough \& Steele, 1985). The supernatant fractions were kept at $0^{\circ}$ until analysed for the activities of malate dehydrogenase ((oxaloacetate decarboxylating) (NADP +)) $(\mathrm{MDH}(\mathrm{NADP}+)$; $E C$ 1.1.1.40), isocitrate dehydrogenase (NADP +) (ICD(NADP +); EC 1.1.1.42) and aspartate aminotransferase (AAT; EC 2.6.1.1).

MDH(NADP +) was determined by a modification of the method of Hsu \& Lardy (1969). The reaction contained 50 mM-HEPES ( $\mathrm{pH} \mathrm{7.5),} 1 \mathrm{mm-NADP,} 5 \mathrm{~mm}-\mathrm{MnCl}_{2}$ and the substrate, $2.2 \mathrm{mM}$-L-malate (disodium salt) in a total volume of $1 \mathrm{ml}$. A $50 \mu \mathrm{l}$ portion of the $50000 \mathrm{~g}$ supernatant fraction (diluted 1:10) was incubated for $5 \mathrm{~min}$ in the presence of the first three ingredients. The reaction was initiated by adding the substrate and following the rate of reduction of NADP at $340 \mathrm{~nm}$ at $25^{\circ}$. The reaction rate was linear for at least 60 min providing that the reaction contained no more than $100 \mu \mathrm{g}$ supernatant protein.

ICD(NADP + ) activity was determined by a modification of the method of Cleland et al. (1969). The reaction contained $50 \mathrm{mm-HEPES} \mathrm{(pH} \mathrm{7.5),} 1 \mathrm{~mm}-\mathrm{NADP}, 5 \mathrm{~mm}-\mathrm{MnCl}_{2}$ and the substrate, $4.4 \mathrm{~mm}$-DL-isocitrate in a total volume of $1 \mathrm{ml}$. A $50 \mu \mathrm{l}$ portion of the $50000 \mathrm{~g}$ supernatant fraction (diluted 1:10) was incubated for $5 \mathrm{~min}$ in the presence of the first three ingredients. The reaction was initiated by adding the substrate and following the rate of reduction of NADP at $340 \mathrm{~nm}$ at $25^{\circ}$. The reaction rate was linear for at least $60 \mathrm{~min}$ providing that the reaction contained no more than $50 \mu \mathrm{g}$ supernatant protein.

AAT was determined by a modification of the method of Martin \& Herbein (1976). The reaction contained $50 \mathrm{mM}$-HEPES, $200 \mathrm{~mm}$-L-aspartate, $0.2 \mathrm{~mm}-\mathrm{NADH}, 1000$ units $/ 1$ malate: NAD + oxidoreductase $(E C 1.1 .1 .37)$ and the substrate, $15 \mathrm{~mm}$-2-oxoglutarate in a total volume of $1 \mathrm{ml}$. A $25 \mu \mathrm{l}$ portion of the $50000 \mathrm{~g}$ supernatant fraction (diluted $1: 10$ ) 
was incubated for $5 \mathrm{~min}$ in the presence of the first four ingredients. The reaction was initiated by adding the substrate and following the rate of oxidation of NADH at $340 \mathrm{~nm}$ at $25^{\circ}$. The reaction rate was linear for at least $30 \mathrm{~min}$ providing that the reaction contained no more than $50 \mu \mathrm{g}$ supernatant protein. Enzyme activities are expressed as $\mu \mathrm{mol}$ product formed/min under the assay conditions (Rosebrough \& Steele, 1985).

\section{Statistical analyses}

The experimental design was considered as $3 \times 3$ factorial arrangement of treatments, with TRP and crude protein being the main treatments. Each treatment was replicated four times. The replicate was a pen of six birds. The experiment was also repeated twice for a total of seventy-two pens and 432 birds. Observations for body-weight changes and feed consumption were derived from data for an entire pen of birds for both repetitions ( $n 8)$. Observations for enzyme activities were derived from data for one bird randomly selected from each pen for both experimental repetitions $(n 8)$. In the case of neurotransmitter data this observation was derived from one bird per pen for the second repetition of the experiment ( $n$ 4). Data were analysed by a two-way ANOVA (Kirk, 1968). The main treatment effects of crude protein level and TRP and their interaction were tested against the residual.

\section{RESULTS \\ Growth and feed consumption}

Table 3 summarizes the effects of dietary crude protein and added TRP on broiler growth and feed consumption. Data are based on total feed consumption and weight gain per pen of birds divided by the number of birds in the respective pens. Birds consuming the diets containing $120 \mathrm{~g}$ crude protein were smaller than birds consuming either of the other two levels of dietary crude protein $(P<0.0001)$. When analysing the effect of added TRP, it was noted that the addition of $16.7 \mathrm{~g} \mathrm{TRP} / \mathrm{kg}$ diet resulted in smaller birds than did the other levels of TRP $(P<0.001)$. The interaction between crude protein and TRP was not statistically significant $(P=0 \cdot 500)$. The same dietary effects were also noted for feed consumption as well as efficiency of feed utilization.

\section{Hepatic enzyme activities}

There was a significant effect of dietary crude protein on the activities of all three enzymes (Table $4 ; P<0.001$ ). An increase in crude protein decreased $\mathrm{MDH}(\mathrm{NADP}+$ ) enzyme activity $(P=0.000)$ while an increase in TRP level decreased enzyme activity $(P=0.001)$. It should be noted that a significant crude protein $\times$ TRP interaction may complicate interpretation of these findings. In contrast, an increase in crude protein increased both ICD(NADP +$)$ and AAT activities $(P=0.000)$. Dietary TRP levels did not affect the activities of either ICD(NADP +$)$ or $\operatorname{AAT}(P=0.245$ and 0.092 respectively).

\section{Brain neurotransmitters}

The effects of both dietary crude protein and TRP levels on brain neurochemical levels are presented in Table 5 . An increase in dietary crude protein decreased both brain NA and DA ( $P=0.006$ and 0.014 respectively). The addition of TRP to the diets had no effect on either NA or DA $(P=0.077$ and 0.887 respectively). The DA:NA ratio was not affected by either crude protein or TRP. Although both crude protein and TRP influenced 5-HT, these main treatment effects were confounded by a crude protein $\times$ TRP interaction $(P=0.013)$. In contrast, only TRP influenced 5-HIAA $(P=0.000)$. Both dietary crude protein and its interaction with TRP had little effect on 5-HIAA $(P=0.661$ and 0.368 respectively). Both crude protein and TRP influenced the 5-HT:5-HIAA ratio $(P=0.013$ and 0.000 
Table 3. Effect of diets containing different levels of crude protein $(C P)$ and added tryptophan (TRP) on growth and feed intake of broiler chickens*

(Mean values with their standard errors for eight pen means per dietary treatment)

\begin{tabular}{|c|c|c|c|c|c|c|c|}
\hline \multirow{2}{*}{$\begin{array}{c}\text { CP } \\
(\mathrm{g} / \mathrm{kg} \text { diet })\end{array}$} & \multirow{2}{*}{$\begin{array}{c}\text { Added TRP } \\
\text { (g/kg diet) }\end{array}$} & \multicolumn{2}{|c|}{ Body weight (g) } & \multicolumn{2}{|c|}{ Feed intake $(\mathrm{g})$} & \multicolumn{2}{|c|}{$\mathrm{F} / \mathrm{G}^{\dagger}$} \\
\hline & & Mean & SE & Mean & SE & Mean & $\mathrm{SE}$ \\
\hline $\begin{array}{l}120 \\
120 \\
120\end{array}$ & $\begin{array}{c}0 \\
1 \cdot 7 \\
16 \cdot 7\end{array}$ & $\begin{array}{l}651 \\
636 \\
458\end{array}$ & $\begin{array}{l}28 \cdot 9 \\
45 \cdot 3 \\
38 \cdot 9\end{array}$ & $\begin{array}{r}1147 \\
1103 \\
887\end{array}$ & $\begin{array}{l}24 \cdot 4 \\
22 \cdot 8 \\
72 \cdot 3\end{array}$ & $\begin{array}{l}2 \cdot 25 \\
2 \cdot 37 \\
2 \cdot 90\end{array}$ & $\begin{array}{l}0.12 \\
0.25 \\
0.31\end{array}$ \\
\hline $\begin{array}{l}210 \\
210 \\
210\end{array}$ & $\begin{array}{l}0 \\
1 \cdot 7 \\
16 \cdot 7\end{array}$ & $\begin{array}{l}975 \\
964 \\
789\end{array}$ & $\begin{array}{l}21 \cdot 8 \\
16 \cdot 3 \\
56 \cdot 1\end{array}$ & $\begin{array}{l}1384 \\
1312 \\
1291\end{array}$ & $\begin{array}{l}50 \cdot 0 \\
51 \cdot 2 \\
24 \cdot 2\end{array}$ & $\begin{array}{l}1 \cdot 65 \\
1 \cdot 58 \\
2 \cdot 12\end{array}$ & $\begin{array}{l}0.06 \\
0.08 \\
0.02\end{array}$ \\
\hline $\begin{array}{l}300 \\
300 \\
300\end{array}$ & $\begin{array}{c}0 \\
1 \cdot 7 \\
16 \cdot 7\end{array}$ & $\begin{array}{l}956 \\
911 \\
843\end{array}$ & $\begin{array}{l}32 \cdot 8 \\
32 \cdot 3 \\
39 \cdot 8\end{array}$ & $\begin{array}{l}1391 \\
1365 \\
1312\end{array}$ & $\begin{array}{l}25.9 \\
30 \cdot 7 \\
39 \cdot 0\end{array}$ & $\begin{array}{l}1.72 \\
1.78 \\
1.88\end{array}$ & $\begin{array}{l}0.02 \\
0.02 \\
0.02\end{array}$ \\
\hline $\begin{array}{l}\text { ANOVA } \\
\text { CP }(P=) \\
\operatorname{TRP}(P= \\
\text { TRP } \times \text { CP }\end{array}$ & $(P=)$ & & & & & & \\
\hline
\end{tabular}

* For details of diets and procedures, see Table 1 and pp. 88-89.

$\uparrow$ Feed intake over $21 \mathrm{~d}(\mathrm{~g}) /$ body-weight gain over $21 \mathrm{~d}(\mathrm{~g})$.

Table 4. Effect of diets containing different levels of crude protein (CP) and added tryptophan (TRP) on hepatic enzyme activities (units/g liver*) of broiler chickens $\dagger$

(Mean values with their standard errors for eight pen means per dietary treatment)

\begin{tabular}{|c|c|c|c|c|c|c|c|}
\hline \multirow{2}{*}{$\begin{array}{c}\mathrm{CP} \\
\text { (g/kg diet) }\end{array}$} & \multirow{2}{*}{$\begin{array}{c}\text { Added } \\
\text { TRP } \\
\text { (g/kg diet) }\end{array}$} & \multicolumn{2}{|c|}{ MDH(NADP +) } & \multicolumn{2}{|c|}{ ICD(NADP +) } & \multicolumn{2}{|c|}{ AAT } \\
\hline & & Mean & SE & Mean & $\mathbf{S E}$ & Mean & $\mathrm{SE}$ \\
\hline $\begin{array}{l}120 \\
120 \\
120\end{array}$ & $\begin{array}{l}0 \\
1 \cdot 7 \\
16 \cdot 7\end{array}$ & $\begin{array}{l}28 \cdot 5 \\
31 \cdot 4 \\
25 \cdot 3\end{array}$ & $\begin{array}{l}1.23 \\
0.88 \\
1.06\end{array}$ & $\begin{array}{l}25 \cdot 5 \\
33 \cdot 1 \\
29 \cdot 8\end{array}$ & $\begin{array}{l}2 \cdot 01 \\
3 \cdot 48 \\
3 \cdot 44\end{array}$ & $\begin{array}{l}55 \cdot 8 \\
52 \cdot 2 \\
49 \cdot 8\end{array}$ & $\begin{array}{l}2 \cdot 90 \\
2 \cdot 32 \\
3 \cdot 73\end{array}$ \\
\hline $\begin{array}{l}210 \\
210 \\
210\end{array}$ & $\begin{array}{c}0 \\
1 \cdot 7 \\
16 \cdot 7\end{array}$ & $\begin{array}{l}17 \cdot 0 \\
14 \cdot 1 \\
11 \cdot 4\end{array}$ & $\begin{array}{l}2.96 \\
1.22 \\
0.93\end{array}$ & $\begin{array}{l}41 \cdot 1 \\
34 \cdot 8 \\
37 \cdot 2\end{array}$ & $\begin{array}{l}3 \cdot 44 \\
3 \cdot 98 \\
5 \cdot 24\end{array}$ & $\begin{array}{r}83 \cdot 4 \\
9 \cdot 3 \\
70 \cdot 4\end{array}$ & $\begin{array}{r}7 \cdot 51 \\
9 \cdot 07 \\
10 \cdot 07\end{array}$ \\
\hline $\begin{array}{l}300 \\
300 \\
300\end{array}$ & $\begin{array}{c}0 \\
1 \cdot 7 \\
16 \cdot 7\end{array}$ & $\begin{array}{l}4 \cdot 8 \\
5 \cdot 1 \\
4 \cdot 1\end{array}$ & $\begin{array}{l}0.62 \\
1.05 \\
0.72\end{array}$ & $\begin{array}{l}63 \cdot 5 \\
43 \cdot 8 \\
48 \cdot 4\end{array}$ & $\begin{array}{l}5 \cdot 96 \\
5 \cdot 17 \\
3 \cdot 74\end{array}$ & $\begin{array}{r}105 \cdot 3 \\
77 \cdot 7 \\
84 \cdot 8\end{array}$ & $\begin{array}{l}8 \cdot 33 \\
9 \cdot 91 \\
9 \cdot 42\end{array}$ \\
\hline $\begin{array}{l}\text { ANOVA } \\
\text { CP }(P=) \\
\text { TRP }(P= \\
\text { TRP } \times \text { CP }\end{array}$ & $\Rightarrow(P=)$ & & & & & & \\
\hline
\end{tabular}

MDH(NADP+), malate dehydrogenase (oxaloacetate decarboxylating) (NADP + ) $(E C 1.1 .1 .40)$, $\mathrm{ICD}(\mathrm{NADP}+)$ isocitrate dehydrogenase $(\mathrm{NADP}+)(E C 1.1 .1 .42)$, AAT, aspartate aminotransferase (EC 2.6.1.1).

* One unit is that amount of enzyme resulting in the production of $1 \mu \mathrm{mol}$ oxidized or reduced $\mathrm{NAD}(\mathrm{P}) / \mathrm{min}$ at $25^{\circ}$.

$\uparrow$ For details of diets and procedures, see Table 1 and pp. 88-91. 
Table 5. Effect of diets containing different levels of crude protein $(C P)$ and added tryptophan $(T R P)$ on brain noradrenaline $(N A)$, dopamine $(D A)$ serotonin $(5-H T)$ and 5-hydroxy-indole3-acetic acid (5-HIAA) concentrations in broiler chickens*

(Mean values with their standard errors for four observations per dietary treatment, expressed as ng/g tissue)

\begin{tabular}{|c|c|c|c|c|c|c|c|c|c|c|c|c|c|}
\hline \multirow{2}{*}{$\begin{array}{c}\text { CP } \\
\text { (g/kg } \\
\text { diet) }\end{array}$} & \multirow{2}{*}{$\begin{array}{c}\text { Added } \\
\text { TRP } \\
\text { (g/kg } \\
\text { diet) }\end{array}$} & \multicolumn{2}{|c|}{$\mathbf{N A}$} & \multicolumn{2}{|c|}{ DA } & \multicolumn{2}{|c|}{ DA/NA } & \multicolumn{2}{|c|}{ 5-HT } & \multicolumn{2}{|c|}{ 5-HIAA } & \multicolumn{2}{|c|}{$\begin{array}{c}\text { 5-HT: } 5- \\
\text { HIAA }\end{array}$} \\
\hline & & Mean & SE & Mean & $\mathrm{SE}$ & Mean & $\mathrm{SE}$ & Mean & SE & Mean & $\mathbf{S E}$ & Mean & $\mathrm{SE}$ \\
\hline 120 & 0 & 398 & $8 \cdot 3$ & 446 & $34 \cdot 8$ & $1 \cdot 11$ & 0.08 & 594 & 29.9 & 225 & $15 \cdot 6$ & 2.69 & 0.07 \\
\hline 120 & 1.7 & 366 & $29 \cdot 6$ & 398 & 30.6 & $1 \cdot 11$ & 0.04 & 536 & 39.8 & 237 & $30 \cdot 6$ & $2 \cdot 49$ & 0.18 \\
\hline 120 & 16.7 & 409 & $15 \cdot 8$ & 451 & 30.5 & $1 \cdot 10$ & 0.04 & 829 & 447 & 498 & $37 \cdot 0$ & $1 \cdot 72$ & 0.08 \\
\hline 210 & 0 & 368 & $18 \cdot 6$ & 325 & $9 \cdot 8$ & 0.91 & 0.06 & 447 & $48 \cdot 7$ & 224 & $15 \cdot 1$ & $2 \cdot 03$ & 0.08 \\
\hline 210 & 1.7 & 345 & $16 \cdot 0$ & 400 & $34 \cdot 2$ & 1.23 & $0 \cdot 15$ & 608 & $40 \cdot 7$ & 288 & $43 \cdot 2$ & $2 \cdot 36$ & 0.12 \\
\hline 210 & $16 \cdot 7$ & 401 & $19 \cdot 2$ & 373 & 26.8 & 0.96 & 0.09 & 586 & $43 \cdot 7$ & 405 & $57 \cdot 6$ & $1 \cdot 76$ & 0.06 \\
\hline 300 & 0 & 336 & $23 \cdot 7$ & 356 & 31.0 & 1.06 & 0.05 & 630 & $59 \cdot 6$ & 223 & $39 \cdot 2$ & $2 \cdot 87$ & 0.13 \\
\hline 300 & $1 \cdot 7$ & 352 & 23.9 & 357 & $24 \cdot 6$ & 1.01 & 0.03 & 570 & 29.8 & 236 & $33 \cdot 1$ & $2 \cdot 53$ & $0 \cdot 17$ \\
\hline 300 & $16 \cdot 7$ & 289 & $28 \cdot 2$ & 343 & $29 \cdot 5$ & $1 \cdot 22$ & 0.06 & 633 & $51 \cdot 1$ & 416 & $49 \cdot 9$ & $1 \cdot 52$ & 0.09 \\
\hline \multicolumn{14}{|c|}{ ANOVA } \\
\hline \multirow{2}{*}{\multicolumn{2}{|c|}{$\begin{array}{l}\mathrm{CP}(P=) \\
\operatorname{TRP}(P=) \\
\operatorname{TRP} \times \mathrm{CP}\end{array}$}} & \multicolumn{2}{|c|}{0.006} & \multicolumn{2}{|c|}{$0-014$} & \multicolumn{2}{|c|}{0.459} & \multicolumn{2}{|c|}{0.019} & \multicolumn{2}{|c|}{0.661} & \multicolumn{2}{|c|}{0.013} \\
\hline & & \multicolumn{2}{|c|}{0.777} & \multicolumn{2}{|c|}{0.887} & \multicolumn{2}{|c|}{0.325} & \multicolumn{2}{|c|}{0.002} & \multicolumn{2}{|c|}{$0 \cdot 000$} & \multicolumn{2}{|c|}{0.000} \\
\hline \multicolumn{2}{|c|}{$(P=)$} & \multicolumn{2}{|c|}{0.088} & \multicolumn{2}{|c|}{0.370} & \multicolumn{2}{|c|}{0.055} & \multicolumn{2}{|c|}{0.013} & \multicolumn{2}{|c|}{0.368} & \multicolumn{2}{|c|}{0.007} \\
\hline
\end{tabular}

* For details of diets and procedures, see Table 1 and pp. 88-90.

Table 6. Effect of diets containing different levels of crude protein $(C P)$ and added tryptophan $(T R P)$ on cardiac and pancreatic noradrenaline $(N A)$ and dopamine $(D A)$ concentrations in broiler chickens*

(Mean values with their standard errors for four pen means per dietary treatment, expressed as $\mathrm{ng} / \mathrm{g}$ tissue)

\begin{tabular}{|c|c|c|c|c|c|c|c|c|c|}
\hline \multirow{3}{*}{$\begin{array}{c}\text { CP } \\
\text { (g/kg } \\
\text { diet) }\end{array}$} & \multirow{3}{*}{$\begin{array}{c}\text { Added } \\
\text { TRP } \\
\text { (g/kg } \\
\text { diet) }\end{array}$} & \multicolumn{6}{|c|}{ Heart } & & \\
\hline & & \multicolumn{2}{|c|}{ NA } & \multicolumn{2}{|c|}{ DA } & \multicolumn{2}{|c|}{ DA: NA } & \multicolumn{2}{|c|}{ Pancreas NA } \\
\hline & & Mean & $\mathrm{SE}$ & Mean & SE & Mean & SE & Mean & $\mathbf{S E}$ \\
\hline 120 & 0 & 231 & $9 \cdot 4$ & 1387 & $367 \cdot 1$ & $6 \cdot 11$ & 1.63 & 446 & $21 \cdot 0$ \\
\hline 120 & $1 \cdot 7$ & 217 & 33.9 & 622 & $269 \cdot 0$ & $2 \cdot 54$ & 0.83 & 481 & $18 \cdot 4$ \\
\hline 120 & $16 \cdot 7$ & 311 & $63 \cdot 6$ & 1219 & 150.0 & $4 \cdot 45$ & $0 \cdot 80$ & 430 & $14 \cdot 8$ \\
\hline 210 & 0 & 341 & $72 \cdot 0$ & 969 & $325 \cdot 0$ & 3.40 & $1 \cdot 19$ & 328 & $45 \cdot 2$ \\
\hline 210 & $1 \cdot 7$ & 363 & $68 \cdot 8$ & 1342 & $342 \cdot 0$ & 4.08 & 0.86 & 322 & $43 \cdot 7$ \\
\hline 210 & $16 \cdot 7$ & 322 & $70 \cdot 5$ & 1286 & $251 \cdot 0$ & $4 \cdot 33$ & 0.85 & 266 & $24 \cdot 4$ \\
\hline 300 & 0 & 347 & $59 \cdot 1$ & 1400 & $510 \cdot 0$ & 3.55 & 1.03 & 271 & $29 \cdot 4$ \\
\hline 300 & $1 \cdot 7$ & 414 & $70 \cdot 2$ & 918 & 498.0 & 1.97 & 0.98 & 260 & 31.0 \\
\hline 300 & $16 \cdot 7$ & 386 & $55 \cdot 8$ & 855 & $339 \cdot 0$ & $2 \cdot 83$ & $1 \cdot 44$ & 363 & $26 \cdot 0$ \\
\hline \multicolumn{10}{|c|}{ ANOVA } \\
\hline \multicolumn{2}{|c|}{$\mathrm{CP}(P=)$} & \multicolumn{2}{|c|}{0.033} & \multicolumn{2}{|c|}{0.304} & \multicolumn{2}{|c|}{0.199} & \multicolumn{2}{|c|}{0.000} \\
\hline \multicolumn{2}{|c|}{$\operatorname{TRP}(P=)$} & \multicolumn{2}{|c|}{0.757} & \multicolumn{2}{|c|}{0.296} & \multicolumn{2}{|c|}{$0 \cdot 247$} & \multicolumn{2}{|c|}{0.960} \\
\hline \multicolumn{2}{|c|}{$\operatorname{TRP} \times \mathrm{CP}(P \Rightarrow)$} & \multicolumn{2}{|c|}{0.623} & \multicolumn{2}{|c|}{0.307} & \multicolumn{2}{|c|}{$0 \cdot 387$} & \multicolumn{2}{|c|}{0.071} \\
\hline
\end{tabular}

* For details of diets and procedures, see Table 1 and pp. 88-90. 
respectively), but interaction between the two $(P=0.007)$ confounds interpretation of main treatment effects.

\section{Heart and pancreas}

Table 6 summarizes the effects of both dietary crude protein and TRP on peripheral concentrations of NA and DA. Dietary protein increased $(P=0.033)$ cardiac NA, decreased $(P=0.000)$ pancreatic NA, but had no effect on cardiac DA $(P=0 \cdot 304)$. Dietary TRP did not affect amines in either hearts or pancreata $(P=0.296$ and 0.960 respectively).

\section{DISCUSSION}

The data from the present study illustrate the caution necessary when studying the effect of added TRP on feed intake. Although prior research indicates little or no effect of supplemental dietary TRP on feed intake, little attention has been given to the basal level of crude protein in these studies (Smith \& Waldroup, 1988; Denbow et al. 1993). In the present study, supplemental TRP decreased feed intake when combined with a low level of crude protein $(120 \mathrm{~g} / \mathrm{kg}$ diet), but not with higher levels $(210$ and $300 \mathrm{~g} / \mathrm{kg}$ ). It could also be argued that, based on the present study, much higher levels of TRP are required to change feed intake. The highest level of supplementation used in the present study was nearly ten times that used in the studies mentioned previously. Thus, our findings show that TRP supplementation to meet a dietary requirement does not result in changes in neurotransmitter metabolism or feed intake.

The present study shows that changes in hepatic intermediary metabolism are also accompanied by changes in brain catecholamine levels. For example, it was noted that increasing dietary crude protein decreased both brain DA and NA concentrations. Accompanying this reduction was a decrease in MDH(NADP+) and an increase in ICD(NADP +) and AAT activities. Since the activities of these enzymes have been used as indicators of changes in lipid and protein respectively (Rosebrough \& McMurtry, 1993), it is possible that a neural-hepatic loop exists to control responses to dietary changes. Pancreatic NA concentrations were inversely related to dietary crude protein. In contrast, cardiac NA concentrations were directly related to dietary crude protein.

The present study, illustrating a relationship between dietary protein intake and cardiac NA levels, agrees with the work of Young et al. (1985) who fed rats on two concentrations of dietary protein $(70$ and $200 \mathrm{~g} / \mathrm{kg}$ ) to study the dynamics of peripheral catecholamine metabolism. They found that cardiac NA concentrations were $15-20 \%$ lower in rats fed on a diet containing a low level of crude protein and that NA turnover was nearly twofold greater. Furthermore, urinary NA excretion was $25 \%$ greater in the group fed on the lowprotein diet. Although tyrosine availability could regulate NA turnover, supplementation of diets with tyrosine did not change turnover rates.

Regretably, these kinds of studies do not hint at the possible mechanisms involved in accelerated catecholamine metabolism in animals fed on low-protein, high-carbohydrate diets. It should be noted that in most studies carbohydrates are substituted for dietary protein sources during diet formulation and that the effect of a high-carbohydrate level cannot always be separated from that of a low protein level. Thus, the argument can always be made that effects are due to an increase in available dietary carbohydrate as well as a decrease in dietary protein. Indeed, Vander Tuig \& Romsos (1984) stated that carbohydrate availability, rather than protein per se is the dietary variable regulating CNS activity. This statement may not be all encompassing because both protein-free and high-protein diets reduce feed intake. Depressed feed intake of rats fed on either of these regimens is accompanied by changes in free indispensable amino acids but is not accompanied by any changes in either 5-HT or 5-HIAA. In addition, diets containing wide variations in amino 
acid quality and balance produce a competition among amino acids for uptake into the brain. This competition results in changes in feeding behaviour but does not change either 5-HT or 5-HIAA (Tackman et al. 1990).

Denbow (1983) and Denbow \& Sheppard (1993) extended these findings to birds by showing that NA increased feed intake when injected into the ventromedial or paraventricular nucleii. The latter site in rat brain was previously shown to be sensitive to NA (Leibowitz, 1978; Leibowitz et al. 1981), possibly through occupancy of $\alpha_{2}$ noradrenergic receptors (Goldman et al. 1985). Although NA-stimulated feeding behaviour in rats was attenuated by 5-HT (Leibowitz \& Shor-Posner, 1986), the role of 5-HT in birds is not well understood. For example, Denbow et al. (1993) reported that even though supplemental dietary TRP increased brain NA, 5-HIAA and 5-HT concentrations, there was no effect on either growth or feed intake.

It is possible that feed intake of chickens fed on diets containing very low levels of crude protein may be affected by TRP through the influence of 5-HT. The value to the chicken of increased NA as a function of low-protein diets probably lies in the ability of these kinds of diets to stimulate fat synthesis. If pancreatic glucagon can be shown to be under the influence of the CNS, the lipolytic characteristics of this hormone may be a natural feedback on the production of excess fat in chickens fed on high-carbohydrate diets. Unlike mammalian liver tissue, the avian liver may not respond to the hormone insulin but is more responsive to the catecholamine family of hormones.

\section{REFERENCES}

Anton, A. H. \& Sayre, D. F. (1962). A study of the factors affecting the aluminum oxide trihydroxyindole procedure for the analysis of catecholamines. Journal of Pharmacology and Experimental Therapeutics 138, $360-375$.

Cleland, W. W., Thompson, V. M. \& Barden, R. E. (1969). Isocitrate dehydrogenase (TPN specific) from pig heart. In Methods in Enzymology, vol, 13, pp. 30-33 [J. M. Lowenstein, editor]. New York: Academic Press.

Colmenares, J. L., Wurtman, R. J. \& Fernstrom, J. D. (1975). Effects of ingestion of a carbohydrate-fat meal on the levels and synthesis of 5-hydroxyindoles in various regions of the rat central nervous system. Journal of Neurochemistry 25, 825-829.

Denbow, D. M. (1983). Food intake and temperature response to injections of catcholamines into the lateral ventricle of the turkey brain. Poultry Science 62, 1088-1092.

Denbow, D. M., Hobbs, F. C., Hulet, R. M., Graham, P. P. \& Potter, L. M. (1993). Supplemental dietary Ltryptophan effects on growth, meat quality, and brain catecholamine and indolamine concentrations in turkeys. British Poultry Science 34, 715-724.

Denbow, D. M. \& Sheppard, B. J. (1993). Food and water intake responses of the domestic fowl to norepinephrine infusion at circumscribed neural sites. Brain Research Bulletin 31, 121-128.

Eriksson, B.-M. \& Persson, B.-A. (1982). Determination of catecholamines in rat heart tissue and plasma samples by liquid chromatography and electrochemical detection. Journal of Chromatography 228, 143-154.

Fernstrom, J. D. (1979). Diet-induced changes in plasma amino acid pattern: effects on the brain uptake of large neutral amino acids, and on brain serotonin synthesis. Journal of Neural Transmission 15, 217-219.

Fernstrom, J. D. (1983). Role of precursor availability in control of monoamine biosynthesis in brain. Physiological Reviews 93, 484-546.

Goldman, C. K., Marino, L. \& Leibowitz, S. F. (1985). Postsynaptic $\alpha_{2}$-noradrenergic receptors mediate feeding induced by paraventricular nucleus injection of norepinephrine and clonidine. European Journal of Pharmacology 115, 11-19.

Hsu, R. Y. \& Lardy, H. A. (1969). Malic enzyme. In Methods in Enzymology, vol. 13, pp. $230-235$ [J. M. Lowenstein, editor]. New York: Academic Press.

Kaufman, L. N., Young, J. B. \& Landsberg, L. (1984). Protein stimulates sympathetic nervous (CNS) activity less than carbohydrate: evidence for nutrient-specific CNS responses. Clinical Research 32, 478-490.

Kaufman, L. N., Young, J. B. \& Landsberg, L. (1989). Differential catecholamine responses to dietary intake: effects of macronutrients on dopamine and epinephrine excretion in the rat. Metabolism 38, 91-99.

Kirk, R. E. (1968). Experimental Design Procedures for the Behavioral Sciences, Belmont, CA: Wadsworth Publishing Company.

Lacy, M. P., Van Krey, H. P., Skewes, P. A., Denbow, D. M. \& Siegel, P. B. (1987). Food intake response of genetically selected high and low-weight line cockerels to plasma infusions from fasted fowl. Poultry Science 66, 1224-1228. 
Leibowitz, S. F. (1978). Paraventricular nucleus: a primary site for mediating adrenergic stimulation of feeding and drinking. Pharmacology and Biochemistry of Behavior 8, 163-175.

Leibowitz, S. F., Hammer, N. J. \& Chang, K. (1981). Hypothalamic paraventricular nucleus lesions produce overeating and obesity in the rat. Physiology of Behavior 27, 1031-1040.

Leibowitz, S. F. \& Shor-Posner, G. (1986). Hypothalamic monoamine systems for control of food intake: analysis of meal patterns and macronutrient selection. In Psycopharmacology of Eating Disorders: Theoretical and Clinical Advances, pp. 29-49 [M. O. Carobe and J. E. Blundel, editors]. New York: Raven Press.

Martin, R. J. \& Herbein, J. H. (1976). A comparison of the enzyme levels and in vitro utilization of various substrates for lipogenesis in pair-fed lean and obese pigs. Proceedings of the Society for Experimental Biology and Medicine 151, 231-235.

Nielsen, J. A., Chapin, D. S., Johnson, J. L. \& Torgersen, L. K. (1992). Sertraline, a serotonin-uptake inhibitor, reduces food intake and body weight in lean and genetically obese mice. American Journal of Clinical Nutrition $55,185 \mathrm{~S}-189 \mathrm{~S}$.

Rosebrough, R. W. \& McMurtry, J. P. (1993). Protein and energy relations in the broiler chicken. 11. Effects of protein quantity and quality on metabolism. British Journal of Nutrition 70, 667-678.

Rosebrough, R. W., McMurtry, J. P. \& Vasilatos-Younken, R. (1992). Metabolic and hormonal effects of feeding chickens thyroxine and diets containing varied calorie:protein ratios. Nutrition Research 12, 77-87.

Rosebrough, R. W. \& Steele, N. C. (1985). Energy and protein relations in the broiler. 1. Effect of protein levels and feeding regimes on growth, body composition, and in vitro lipogenesis of broiler chicks. Poultry Science 64, 119-126.

Schwartz, J. H., Young, J. B. \& Landsberg, L. (1983). Effect of dietary fat on sympathetic nervous system activity in the rat. Journal of Clinical Investigation 72, 361-370.

Smith, N. K. \& Waldroup, P. W. (1988). Estimation of the tryptophan requirement of male broiler chickens. Poultry Science 67, 1174-1177.

Tackman, J. M., Tews, J. K. \& Harper, A. E. (1990). Dietary disproportions of amino acids in the rat: effects on food intake, plasma and brain amino acids and brain serotonin. Journal of Nutrition 120, 521-533.

Vander Tuig, J. G. \& Romsos, D. R. (1984). Effects of dietary carbohydrate, fat, and protein on norepinephrine turnover in rats. Metabolism 33, 26-33.

Young, J. B., Kaufman, L. N., Savile, M. E. \& Landsberg, L. (1985). Increased sympathetic nervous system activity in rats fed a low-protein diet. American Journal of Physiology 248, R267-R637.

Young, J. B. \& Landsberg, L. (1977a). Suppression of sympathetic nervous system during fasting. Science 196, $1473-1475$.

Young, J. B. \& Landsberg, L. (1977b). Stimulation of the sympathetic nervous system during sucrose feeding. Nature 269, 615-617. 